\title{
Geosmin off-flavour in pond-raised fish in southern Bangladesh and occurrence of potential off-flavour producing organisms
}

\author{
Mikael A. Petersen ${ }^{1}$, Md. Ariful Alam ${ }^{2}$, Md. Mizanur Rahman ${ }^{2}$, Md. Lokman Ali ${ }^{2}$, \\ Sultan Mahmud ${ }^{2}$, Louise Schlüter ${ }^{3}$, Niels O. G. Jørgensen ${ }^{4, *}$ \\ ${ }^{1}$ Department of Food Science, University of Copenhagen, Thorvaldsensvej 40, 1871 Frederiksberg, Denmark \\ ${ }^{2}$ Faculty of Fisheries, Patuakhali Science and Technology University, Dumki, Patuakhali 8602, Bangladesh \\ ${ }^{3}$ Environment and Toxicology, DHI Group, Agern Allé 5, 2970 Hørsholm, Denmark \\ ${ }^{4}$ Genetics and Microbiology, Department of Plant and Environmental Sciences, University of Copenhagen, \\ Thorvaldsensvej 40, 1871 Frederiksberg, Denmark
}

\begin{abstract}
Pangas Pangasianodon hypophthalmus and tilapia Oreochromis niloticus were cultivated for 6 mo in earthen ponds in Bangladesh to examine occurrence of the off-flavour geosmin in water and fish and to test procedures for reduction of off-flavour. In the ponds $(\sim 1 \mathrm{~m}$ depth and area of $400 \mathrm{~m}^{2}$ ), the average geosmin concentration was $3.9 \mathrm{ng} \mathrm{l}^{-1}$ (range 0.2 to $20 \mathrm{ng} \mathrm{l}^{-1}$ ). No effects of season or water treatment (sand filtration or probiotic microbes) were found. The content of geosmin in the fish was $21 \mathrm{ng} \mathrm{kg}^{-1}$ (range: 0.0 to $91 \mathrm{ng} \mathrm{kg}^{-1}$ ) for pangas and $17 \mathrm{ng} \mathrm{kg}^{-1}$ (range: 0.0 to $68 \mathrm{ng} \mathrm{kg}^{-1}$ ) for tilapia. Water treatment reduced the geosmin content by 56 to $74 \%$ in pangas, but no effect was found in tilapia. Likewise, depuration for $\geq 12 \mathrm{~h}$ in groundwater lowered the geosmin content in pangas (by 65 to $90 \%$ ) but not in tilapia. Sensory analysis indicated a positive effect of both water treatment and depuration, and the fish were graded 'no or mild flavour' after such treatment, compared to 'strong off-flavour' in controls. Abundance analyses of known offflavour producing microorganisms (streptomycete bacteria and cyanobacteria) showed a high density of streptomycetes ( 0.5 to $13 \%$ of the bacterial population), while cyanobacteria made up a maximum of $9.3 \%$ of the phytoplankton biomass or were absent. This first study on off-flavours in pangas and tilapia in Bangladeshi ponds indicates that geosmin was not a major off-flavour in the fish, but improvement of sensory quality by water treatment and depuration suggests that other, unidentified off-flavours were present in the fish.
\end{abstract}

KEY WORDS: Off-flavour - Aquaculture - Pangasianodon hypophthalmus · Oreochromis niloticus · Streptomycetes $\cdot$ Cyanobacteria $\cdot$ Geosmin $\cdot$ GC-MS $\cdot$ Sensory analysis

\section{INTRODUCTION}

Taste-and-odour compounds (TOCs) can reduce the palatability of freshwater fish produced in aquaculture systems, especially when water recirculation is applied (Robertson \& Lawton 2003, Smith et al.
2008). The most commonly identified TOCs are geosmin (earthy flavour) and 2-methylisoborneol (MIB; mildewed flavour), and both of these offflavours have been shown to concentrate 200- to 400fold in fish flesh, relative to the ambient concentration (Howgate 2004). TOCs are produced by several

*Corresponding author: nogj@plen.ku.dk 
species of cyanobacteria (also known as blue-green algae) and by non-photosynthetic Streptomyces bacteria (Gram-positive, filamentous bacteria), but recent research indicates that other bacteria, e.g. species within the order Myхосоccales, may also produce off-flavours in some aquaculture systems (Zaitlin \& Watson 2006, Auffret et al. 2013).

TOCs impact taste and flavour of fish in both warm- and cold-water aquaculture systems. In warm water, tainting by geosmin and MIB was observed in barramundi Lates calcarifer from freshwater lakes in northern Australia (Percival et al. 2008), in catfish Ictalurus punctatus from ponds in Mississippi and Alabama, USA (Schrader \& Dennis 2005), and in tilapia Oreochromis niloticus reared in pond cages in Thailand (Gutierrez et al. 2013). In cold-water systems, tainting of rainbow trout Oncorhynchus mykiss by geosmin and MIB was detected in outdoor tanks with recirculation in Denmark (Petersen et al. 2011) and in arctic charr Salvelinus alpinus from an indoor system with water recirculation in West Virginia, USA (Houle et al. 2011). TOCs reduce market value of fish from aquaculture due to consumer reluctance to buy food with an earthy or mildewed taste, but the actual reduction in market value of fish due to tainting is difficult to determine. For American catfish, TOCs have been estimated to reduce the sale by $30 \%$ (Engle et al. 1995).

In Bangladesh, occurrence of off-flavour in pangasiid catfish has been reported for fish reared in ponds (Khan et al. 2009), but the extent of off-flavour problems in pond-raised fish in Bangladesh has not been scientifically documented. Various treatments of fish meat to reduce off-flavours are practised in Bangladesh and Indian households, e.g. dipping and washing in tamarind pulp, lemon juice, lemon grass, salt solution, or a suspension of banana leaf ash, and some of these treatments appear to improve the sensory quality of the fish (Mohsin et al. 1999).

In large and industrial aquaculture systems, offflavours in fish may be reduced by depuration for few to several days in clean water and without feed before slaughtering (Robertson et al. 2005, Percival et al. 2008). Depuration is an efficient procedure for off-flavour reduction, but access to clean and offflavour-free water may be limited, and the fish lose weight (and hereby value) during the treatment (Burr et al. 2012).

In this study, the presence of geosmin and procedures for its removal from water and fish were examined in tilapia Oreochromis niloticus and pangas Pangasianodon hypophthalmus (also known as pangasius), reared in local earthen ponds in southern
Bangladesh (Dumki Upazila). The 2 fish species constitute a major source of animal protein to the local population, and both species are of large economic importance (Ahmed et al. 2012). When considering the importance of the 2 fish species, the lack of studies on sources of the reported off-flavour problems (see above) is surprising. In southeast Asia, the content of geosmin has been examined in tilapia in Thai fish ponds (Gutierrez et al. 2013), but the content of off-flavours in wild or farmed pangas has not previously been measured. Here, we determined the content of geosmin in water and fish (tilapia and pangas) by a dynamic headspace extraction method and GCMS detection. MIB was targeted for inclusion in the study, but the compound could not be quantified with an acceptable accuracy. In addition, the taste and flavour of the fish were characterized by sensory analysis. Different procedures were applied to reduce potential off-flavours in water and fish, including sand filtration and probiotic treatment of the pond water during the production phase as well as depuration of the fish in groundwater before slaughtering. The presence of potential off-flavour producing organisms (cyanobacteria and streptomycetes) in the water was examined by a chromatographic method (for cyanobacteria) and a molecular approach (for streptomycetes).

\section{MATERIALS AND METHODS}

\section{Set-up and sampling}

Details on ponds, experimental set-up, growth rates of fish and water quality are reported separately (S. Mahmud et al. unpubl.). Briefly, 8 earthen ponds of 309 to $497 \mathrm{~m}^{2}$ area and with depth of 1.1 to $1.6 \mathrm{~m}$ were selected in Dumki Upazila, Patuakhali, in southern Bangladesh $\left(22^{\circ} 21^{\prime} 15^{\prime \prime} \mathrm{N}, 90^{\circ} 23^{\prime} 21^{\prime \prime} \mathrm{W}\right)$. Each pond received 50 tilapia Oreochromis niloticus fry (5.2 to $5.3 \mathrm{~g}$ each) and 30 pangas Pangasianodon hypophthalmus fry (62 to $75 \mathrm{~g}$ each) in late January 2012. The fish were fed artificial feed (Mega Fish sinking feed pellets; www.spectragroup.com.bd) at the rate of $30 \%$ of their body weight for first month, $20 \%$ for the next month and 3 to $10 \%$ for the last 4 mo. Planktonic matter in the ponds is another important food source to the fish. After 6 mo, the fish had grown to 182-199 g (tilapia) and 689-870 $\mathrm{g}$ (pangas). At termination of the study (early August 2012), selected fish were taken for depuration in cement tanks with $\sim 2 \mathrm{~m}^{3}$ groundwater for up to $48 \mathrm{~h}$. The water was not exchanged and no agitation was 
applied during the depuration. After slaughtering, each of the fish were divided into 2 fillets. One fillet was used for chemical analysis of content of geosmin and MIB in the flesh, while the other fillet was used for sensory analyses (see 'Sensory profiling of fish'). The fillets were kept frozen in individual plastic bags at $-20^{\circ} \mathrm{C}$ until analysis.

To test the effect of water treatment on the content of off-flavour sources in the water, the following treatments were performed in duplicates ( 2 ponds for each treatment): continuous filtration of the water through a sand filter, addition of probiotic material, either PondPlus ${ }^{\circledR}$ by Novozymes (www.novozymes. com) or AquaPhoto by ACI (www.aci-bd.com) at weekly intervals according to the producer's instructions, or no treatment (controls). The probiotic products are designed to improve remineralisation of inorganic nutrients to promote growth of fish-beneficial phytoplankton.

Samples for analysis of off-flavours in the water were collected every second month. Volumes of $10 \mathrm{ml}$ water were transferred in duplicates to $20 \mathrm{ml}$ glass vials and treated with $3 \mathrm{~g} \mathrm{NaCl}$ before capping with silicone-PTFE seals and were kept at $4^{\circ} \mathrm{C}$ until analysis. To detect potential off-flavour producing organisms in the water, volumes of 200 and $500 \mathrm{ml}$ water were filtered through $47 \mathrm{~mm}$ diameter $0.2 \mu \mathrm{m}$ pore size cellulose nitrate membrane filters (for Streptomyces bacteria) or $47 \mathrm{~mm}$ diameter GA 100 GF/F filters (for cyanobacteria; www.advantecmfs. com) (see below). The filters were folded and wrapped individually in aluminium foil and kept at $-20^{\circ} \mathrm{C}$ until analysis.

\section{Dynamic headspace sampling of volatiles (including geosmin) in water and fish}

Volatiles were extracted from water samples and fish flesh by dynamic headspace sampling using procedures similar to those applied by Petersen et al. (2011). Briefly, water samples were transferred to a gas-washing bottle, which was immediately closed with a purge head. The bottles were purged with $100 \mathrm{ml}$ of $\mathrm{N}_{2} \mathrm{~min}^{-1}$ for $60 \mathrm{~min}$ in a water bath at $37^{\circ} \mathrm{C}$, simultaneous with collection of volatiles on Tenax TA traps. To extract volatiles from the fish fillets, $10 \mathrm{~g}$ of fish flesh was transferred to a gas-washing bottle with $20 \mathrm{ml}$ of water and $100 \mu \mathrm{l}$ of internal standard solution (5 mg 4-methyl-1-pentanol $\mathrm{l}^{-1}$ ). The flesh was homogenized for $45 \mathrm{~s}$ at $13500 \mathrm{rpm}$ using an Ultra Turrax homogenizer (www.ika.com) followed by rinsing with $10 \mathrm{ml}$ of water before immediate clos- ing with a purge head. The bottles were purged with $100 \mathrm{ml}$ of $\mathrm{N}_{2} \mathrm{~min}^{-1}$ for $60 \mathrm{~min}$ in a water bath at $50^{\circ} \mathrm{C}$ with simultaneous collection of the volatiles on Tenax TA traps. After headspace sampling, the Tenax traps were dried at $100 \mathrm{ml} \mathrm{min}^{-1}$ flow of dry $\mathrm{N}_{2}$ for $10 \mathrm{~min}$.

\section{Analysis of volatiles by GC-MS}

Volatiles were stripped from the traps in an automatic 2-step thermal desorption unit (ATD 400; Perkin Elmer). In the first step, the volatiles were desorbed by heating to $250^{\circ} \mathrm{C}$ at $60 \mathrm{ml} \mathrm{He} \min ^{-1}$ for $15 \mathrm{~min}$. The volatiles were focussed on a cold $\left(5^{\circ} \mathrm{C}\right)$ Tenax TA trap that subsequently was heated to $300^{\circ} \mathrm{C}$ for $4 \mathrm{~min}$ (second step). The 2 -step procedure allowed for a rapid transfer of volatiles to a GC-MS (7890A GC system interfaced with a 5975C VL MSD with a Triple-Axis detector; www.agilent.com) by a heated $\left(225^{\circ} \mathrm{C}\right)$ transfer line.

The volatiles were separated on a DB-Wax capillary column $(30 \mathrm{~m} \times 0.25 \mathrm{~mm}$ internal diameter and

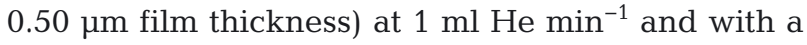
temperature program of $40^{\circ} \mathrm{C}(10 \mathrm{~min})$ and $8^{\circ} \mathrm{C} \mathrm{min}^{-1}$ until $240^{\circ} \mathrm{C}$ (5 min). The mass spectrometer was operated in electron ionization mode at $70 \mathrm{eV}$, and massto-charge ratios between 15 and 300 were scanned. Simultaneously, data were collected in selected ion monitoring mode, monitoring mass 95 for MIB and mass 112 for geosmin. Peak identity was confirmed by probability-based matching of mass spectra with those of a commercial database (Wiley275.L, HP product no. G1035A) and by comparison with retention times of authentic standards. For analysis of the acquired data, MSD Chemstation software (v. E.02.00, Agilent Technologies) was used. For absolute quantification of geosmin and MIB in fish meat, amounts of $0.25,1$, and $4 \mu \mathrm{g} \mathrm{kg}^{-1}$ were added to meat from 4 selected fish during homogenization. Correspondingly, absolute quantification of water samples was carried out by adding 1, 5, 10, 50, and $100 \mathrm{ng} \mathrm{l}^{-1}$ to samples of $10 \mathrm{ml}$ water with $3 \mathrm{~g} \mathrm{NaCl}$. Serial dilutions of the geosmin and MIB stocks (in methanol; products G5908 and M3933, www.sigmaaldrich.com) were performed in ethanol, but water was used for the most dilute concentrations. An acceptable linearity between peak area and concentration was observed $\left(R^{2}=0.91\right.$ to 0.93$)$, and the obtained graphs were used to generate peak area-toconcentration calibration curves. MIB was identified in most of the chromatograms but co-eluted with an unknown compound. Therefore, no results for MIB in water or fish are presented. 
Table 1. Categories for sensory analysis of fish

\begin{tabular}{|lcc|}
\hline Off-flavour level & Grade & Numeric score \\
\hline Strong & A & 1.0 to 2.5 \\
Medium & B & 2.5 to 5.0 \\
Mild & C & 5.0 to 7.5 \\
No off-flavour & D & 7.5 to 10.0 \\
\hline
\end{tabular}

\section{Sensory profiling of fish}

Sensory evaluation of the fish was performed at Patuakhali Science and Technology University by a panel of 10 people. The panel members were not trained in off-flavour characterization but consisted of typical local consumers of freshwater fish: 2 members of the Fish Breeder Community Based Organization (CBO), 2 teachers and 2 students at Patuakhali Science and Technology University, 2 business persons, and 2 local fish farmers. The sensory participants did not receive training in identification of geosmin or MIB before the tests but were asked to categorize the fish flavour (Table 1). Fillets from the fish were prepared in boiling water for $10 \mathrm{~min}$, divided in 10 pieces, and served randomly and without identification to the panel members.

\section{Identification of potential off-flavour producing organisms}

Densities of Streptomyces bacteria in the water were determined by quantitative PCR (TaqMan procedure) targeting the 23S rRNA gene according to Rintala \& Nevalainen (2006) with the modifications given by Lylloff et al. (2012). Genomic DNA was extracted from the $47 \mathrm{~mm}$ membrane filters after cutting each filter in 3 portions, using the PowerWater ${ }^{\circledR}$ DNA isolation kit by Mobio (www.mobio.com) according to instructions by the producer. The PCR reactions were performed in an Mx3000P Stratagene system (www.genomics.agilent.com) using TaqMan Universal PCR Master Mix (www.appliedbiosystems.com). Densities of Streptomyces on the filters were determined from calibration curves produced by amplification of DNA from known densities of spores in 2 species of Streptomyces. Possible interference on the PCR reaction by compounds in the samples was checked by measuring the amplification efficiency of a plasmid construct with and without addition of DNA extracted from the water samples (Lylloff et al. 2012).
Densities of cyanobacteria were estimated from the composition and concentration of specific pigments in the phytoplankton according to Schlüter et al. (2004). The GF/F filters were transferred to vials with $95 \%$ acetone with internal standard (vitamin E). The samples were vortexed, sonicated on ice, extracted at $4{ }^{\circ} \mathrm{C}$ for $20 \mathrm{~h}$, and mixed again. The extracts were filtered through $0.2 \mu \mathrm{m}$ Teflon syringe filters into HPLC vials and placed in the cooling rack $\left(4^{\circ} \mathrm{C}\right)$ of the HPLC system together with a parallel set of vials with injection buffer (28 mM aqueous tetrabutyl ammonium acetate [TBA] at $\mathrm{pH} 6.5$ and methanol, in a 90:10 ratio). The extracts were injected by programming the auto-injector to make a sandwich injection of buffer and sample in the ratio 5:2. The total injection volume was $500 \mu \mathrm{l}$. For detection of the pigments, a Shimadzu LC-10A HPLC system was used following the method by Van Heukelem \& Thomas (2001) (with slight modifications as given below). The HPLC system consisted of a LC-10ADVP pump, an SPD-M10A VP photodiode array detector, an SCL10ADVP System controller with Lab Solution software, an auto sampler (set at $4^{\circ} \mathrm{C}$ ), a column oven (CTO-10ASVP), and a degasser. The column was an Eclipse XDB C8, $4.6 \mathrm{~mm} \times 150 \mathrm{~mm}$ (Agilent Technologies) operated at $60^{\circ} \mathrm{C}$. The solvents were (A) methanol and $28 \mathrm{mM}$ aqueous TBA at pH 6.4 in a 70:30 ratio and (B) $100 \%$ methanol. The following time programming was used: $0 \mathrm{~min}: 95 \% \mathrm{~A}, 5 \% \mathrm{~B} ; 27 \mathrm{~min}$ : $5 \% \mathrm{~A}, 95 \% \mathrm{~B} ; 34 \mathrm{~min}: 5 \% \mathrm{~A}, 95 \% \mathrm{~B} ; 35 \mathrm{~min}: 0 \% \mathrm{~A}$, $100 \% \mathrm{~B}_{;} 38 \mathrm{~min}: 0 \% \mathrm{~A}, 100 \% \mathrm{~B} ; 39.5 \mathrm{~min}: 95 \% \mathrm{~A}$, $5 \% \mathrm{~B}_{;} 50 \mathrm{~min}$ : stop. The flow rate was $1.1 \mathrm{ml} \mathrm{min}^{-1}$. The analysis was calibrated with pigment standards from DHI Lab Products. The internal standard was detected at $222 \mathrm{~nm}$, while the phytoplankton pigments were detected at $450 \mathrm{~nm}$. Peak identities were routinely confirmed by on-line PDA analysis.

Pigment concentrations were subsequently loaded into the CHEMTAX 1.95 program to calculate chlorophyll a biomass of individual phytoplankton groups according to Mackey et al. (1996) and Higgins et al. (2011). Pigment ratios used as input values for CHEMTAX calculations were from Schlüter et al. (2006).

\section{RESULTS AND DISCUSSION}

\section{Geosmin in water}

Occurrence of geosmin in the water from the 4 types of ponds (sand filtration, PondPlus or AquaPhoto enrichment, and untreated controls) were 
rather similar during the 6 mo period with bimonthly sampling of duplicate ponds. Mean concentrations of geosmin (in $\mathrm{ng} \mathrm{l}^{-}$) in the pond water were 4.5 (range: 1.0 to 14.6 ) with sand filtration, 3.4 (range: 0.3 to 20.0 ) for enrichment with PondPlus, 3.7 (range: 0.2 to 16.1 ) for enrichment with AquaPhoto, and 4.1 (range 0.6 to 8.1) for the controls. Mean concentration of geosmin in all water samples was $3.9 \mathrm{ng} \mathrm{l}^{-1}$, and only 3 of 56 water samples had geosmin concentrations $>10 \mathrm{ng}$ $\mathrm{l}^{-1}$. No significant effects of water treatment or seasonality were observed ( $\mathrm{p}>0.05$; $t$-test).

Occurrence of geosmin in the pond water is low relative to concentrations measured in other fish ponds in warm water, e.g. catfish ponds in Louisiana, USA (4 to $246 \mathrm{ng} \mathrm{l}^{-1}$; Hurlburt et al. 2009), and barramundi ponds in Queensland, Australia (range $<1$ to $14370 \mathrm{ng} \mathrm{l}^{-1}$, typical level of $1000 \mathrm{ng} \mathrm{l}^{-1}$; Jones et al. 2013). Geosmin concentrations in the Patuakhali ponds more resembled levels measured in cold stream water $\left(<20^{\circ} \mathrm{C}\right)$, e.g. in Denmark, where levels of geosmin in inlet water of traditional fishponds were $<10 \mathrm{ng} \mathrm{l}^{-1}$ (Klausen et al. 2005). The low level of geosmin, as well as the lack of effects of the different treatments, suggests that geosmin-producing organisms were not abundant in the water, as discussed below.

\section{Geosmin in fish}

Mean concentration of geosmin in meat from all the analysed fish was $21 \mathrm{ng} \mathrm{\textrm {kg } ^ { - 1 }}$ for pangas Pangasianodon hypophthalmus (range 0 to $91 \mathrm{ng} \mathrm{kg}^{-1}$ ) and $17 \mathrm{ng} \mathrm{kg}^{-1}$ for tilapia Oreochromis niloticus (range: 0 to $68 \mathrm{ng} \mathrm{kg}^{-1}$ ). Statistical analyses showed that there was a systematic effect of water treatment and depuration on the content of geosmin in the fish. An initial ANOVA test demonstrated significant interaction between both fish species and effect of water treatment and between fish species and the duration of depuration. Therefore, data from pangas and tilapia are treated separately. For pangas, treatment of the pond water reduced the level of geosmin by 56 to $74 \%$ relative to the content in fish from the control ponds (Table 2). The effect of the 3 treatment types (PondPlus, AquaPhoto, and sand filter) was not significantly different. In contrast, for tilapia, no significant effect of any of the water treatments on the content of geosmin was observed. In fish from the control ponds, a lower content of geosmin was found in tilapia (11 $\mathrm{ng} \mathrm{kg}^{-1}$ ) than in pangas $\left(54 \mathrm{ng} \mathrm{kg}^{-1}\right)$, but this difference was not observed in the other water treatments (Table 2).
Table 2. Mean concentrations (least squares, from ANOVA) of geosmin (ng kg-1 wet weight) in meat from fish from ponds with different water treatments. For each species, treatments not marked with the same letter (A or B) are significantly different $(\mathrm{p}<0.05)$. $n$ : number of analyzed fish

\begin{tabular}{|lcccc|}
\hline Water treatment & Pangas & $\mathrm{n}$ & Tilapia & $\mathrm{n}$ \\
\hline $\begin{array}{l}\text { Control } \\
\text { (no water treatment) }\end{array}$ & $54 \mathrm{~A}$ & 6 & $11 \mathrm{~A}$ & 6 \\
PondPlus & $24 \mathrm{~B}$ & 5 & $24 \mathrm{~A}$ & 6 \\
Sand filter & $18 \mathrm{~B}$ & 6 & $23 \mathrm{~A}$ & 6 \\
AquaPhoto & $14 \mathrm{~B}$ & 6 & $12 \mathrm{~A}$ & 5 \\
\hline
\end{tabular}

Table 3. Mean concentrations (least squares, from ANOVA) of geosmin (ng kg-1 wet weight) in meat from fish from ponds with different depuration times. For each species, depuration times not marked with the same letter are significantly different $(p<0.05)$. n: number of analyzed fish

\begin{tabular}{|lrrrr|}
\hline Depuration time & Pangas & $\mathrm{n}$ & Tilapia & $\mathrm{n}$ \\
\hline Control (no depuration) & $54 \mathrm{~A}$ & 6 & $11 \mathrm{~A}$ & 6 \\
$12 \mathrm{~h}$ & $5 \mathrm{~B}$ & 6 & $8 \mathrm{~A}$ & 6 \\
$24 \mathrm{~h}$ & $12 \mathrm{~B}$ & 3 & $39 \mathrm{~A}$ & 2 \\
$36 \mathrm{~h}$ & $19 \mathrm{~B}$ & 6 & $13 \mathrm{~A}$ & 5 \\
$48 \mathrm{~h}$ & $16 \mathrm{~B}$ & 5 & $15 \mathrm{~A}$ & 2 \\
\hline
\end{tabular}

Depuration of the fish for 12 to $48 \mathrm{~h}$ had a significant effect in pangas, in which the geosmin content was reduced to 65 to $90 \%$ of the level in the control fish (Table 3). No effects of duration of the depuration time (12 to $48 \mathrm{~h}$ ) were found. For tilapia, the depuration did not affect the content of geosmin in the flesh.

The concentration of geosmin in tilapia and pangas in the present ponds is low compared to geosmin content in tilapia in other studies, e.g. fish from cages in Thailand. Gutierrez et al. (2013) measured 0.49 to $3.51 \mu \mathrm{g}$ geosmin $\mathrm{kg}^{-1}$ wet weight in a seasonal study of tilapia cultured in pond cages in northern Thailand. The relatively large content (10- to 70 -fold above the level in tilapia in the Patuakhali ponds) may reflect the higher concentrations of geosmin in the pond water (0.41 to $2.33 \mu \mathrm{g} \mathrm{l}^{-1}$, or 100 - to 600 -fold above the level in the Patuakhali ponds). In addition to geosmin, high levels of MIB were measured in both fish and water in tilapia in the Thai ponds.

The geosmin content in tilapia and pangas was also low relative to barramundi from cages in freshwater in tropical Australia. Jones et al. (2013) reported concentrations of 0.74 to $4.47 \mu \mathrm{g}$ geosmin $\mathrm{kg}^{-1}$ wet weight (13- to 82-fold above the levels in Patuakhali fish). The larger geosmin content in the barramundi 
may reflect the high geosmin concentration in the water ( $<1$ to $14.4 \mathrm{\mu g} \mathrm{l}^{-1}$, or up to 3700 -fold higher than in the Bangladeshi ponds). No data for geosmin content in pangas are available in the literature.

The higher content of geosmin in pangas than in tilapia (54 vs. $11 \mathrm{ng} \mathrm{kg}^{-1}$ ) from the control ponds was unexpected since similar concentrations of geosmin were found in the 2 fish species (12 to $24 \mathrm{ng} \mathrm{kg}^{-1}$ ) from all ponds with water treatments. We have no explanation for the greater geosmin content in pangas from the control ponds. The ponds in this study are individual, earthen, rain-fed ponds, and speculatively, environmental conditions in the 2 adjacent pangas control ponds were similar, e.g. with respect to general water quality, vegetation, shading, and influence from livestock and households, but might have differed from the other ponds. Feeding habits of the fish may also have influenced the geosmin content, although the mechanisms are not clear. Tilapia is a 'column feeder' fish, but it can also feed on benthos and ingest mud, while pangas tend to prefer artificial feed in the water column if feed is available (data not shown). Sediment in lakes has previously been found to harbour higher concentrations of geosmin than the water above (Nielsen et al. 2006). However, the occurrence of geosmin in bottom material of the ponds is unknown, and more research is needed to determine possible relations between feeding habits, feed sources, and levels of off-flavour compounds in fish.

\section{Effect of depuration on geosmin content in fish}

The positive effect in pangas of depuration for 12 to $48 \mathrm{~h}$ in groundwater (reduction of the geosmin content to about one-third of the original value), but not for tilapia, shows that even a short depuration period can purge geosmin from pangas. Tilapia had a low content of geosmin before depuration, and this might explain the lack of effect from the depuration. Unfortunately, the geosmin content of the groundwater used for the depuration is unknown, and the groundwater might have had a variable geosmin content, affecting the geosmin content of the fish. For cold-water fish, such as rainbow trout, depuration periods of $\sim 1 \mathrm{wk}$ are typically practised (Petersen et al. 2011) and are supported by experimental studies of off-flavour depuration in this species (Howgate 2004). Possibly, the high water temperature $\left(\sim 30^{\circ} \mathrm{C}\right)$ in this study increased the release of geosmin in pangas, e.g. due to a higher metabolic activity.

\section{Sensory analysis of off-flavour}

For pangas, grading of the off-flavour level by the panel members largely reflected the geosmin content determined by the chemical analysis. Fish from the control ponds had the highest grading (strong offflavour) relative to PondPlus (medium off-flavour), sand filter (mild off-flavour), and AquaPhoto (no offflavour) treatments (Table 4). For tilapia, the grading pattern was similar, except that the treatments with sand filter and AquaPhoto were similar (mild offflavour) (Table 5). Thus, AquaPhoto treatment and sand filtration were most efficient in reducing the offflavour content of the fish, followed by PondPlus.

Depuration of pangas and tilapia in tanks with groundwater significantly reduced the perceived offflavour relative to control fish. In pangas, all fish were categorized as flavour-free (grade D) after $12 \mathrm{~h}$ depuration, although a depuration time of $\geq 24$ h gave a slightly higher numeric score (Table 6). For tilapia, all fish were given a score of mild off-flavour (grade C) after 12 to $48 \mathrm{~h}$ of depuration. No data on geosmin concentrations in the groundwater are available, but the decline in geosmin content in the fish suggests a lower content than in the pond water.

The coincidence between a lower geosmin content and 'less off-flavour' grading after depuration, as

Table 4. Off-flavour profiling of pangas from ponds with different treatment. Numeric scores of grades (see Table 1) are mean $\pm \mathrm{SE} ; \mathrm{n}=48$ (12 from each pond treatment). The grading was statistically different for each water treatment type $(\mathrm{p}<0.05$; ANOVA $)$

\begin{tabular}{|lcc|}
\hline Water treatment & Average grade & Off-flavour level \\
\hline Control & $2.4 \pm 0.2$ & Strong (A) \\
PondPlus & $4.8 \pm 0.8$ & Medium (B) \\
Sand filter & $7.1 \pm 1.1$ & Mild (C) \\
AquaPhoto & $7.8 \pm 0.1$ & No off-flavour (D) \\
\hline
\end{tabular}

Table 5. Off-flavour profiling of tilapia from ponds with different treatment. Numeric scores of grades (see Table 1) are mean $\pm \mathrm{SE}_{;} \mathrm{n}=48$ (12 from each pond treatment). The grading was statistically different for each water treatment type $(\mathrm{p}<0.05$; ANOVA) except between the sand filter and AquaPhoto treatments

\begin{tabular}{|lcc|}
\hline Water treatment & Average grade & Off-flavour level \\
\hline Control & $2.7 \pm 0.0$ & Strong (A) \\
PondPlus & $4.9 \pm 0.1$ & Medium (B) \\
Sand filter & $6.2 \pm 0.3$ & Mild (C) \\
AquaPhoto & $6.5 \pm 0.2$ & Mild (C) \\
\hline
\end{tabular}


Table 6. Off-flavour profiling of fish without and with depuration for varying time periods. Mean numeric scores of grades (see Table 1) \pm SE are shown; $\mathrm{n}=$ 40 (4 fish of each species from each treatment). Treatments not marked with the same letter (A, B and $C)$ are significantly different $(p<0.05$; ANOVA)

\begin{tabular}{lccccc}
$\begin{array}{l}\text { Fish } \\
\text { species }\end{array}$ & $\begin{array}{c}\text { No } \\
\text { depuration }\end{array}$ & $12 \mathrm{~h}$ & $24 \mathrm{~h}$ & $36 \mathrm{~h}$ & $48 \mathrm{~h}$ \\
\hline Pangas & $2.4 \pm 0.1 \mathrm{~A}$ & $7.9 \pm 0.2 \mathrm{~B}$ & $9.2 \pm 0.2 \mathrm{C}$ & $9.0 \pm 0.2 \mathrm{C}$ & $8.7 \pm 0.2 \mathrm{C}$ \\
Tilapia & $2.4 \pm 0.2 \mathrm{~A}$ & $6.7 \pm 0.3 \mathrm{~B}$ & $6.9 \pm 0.2 \mathrm{~B}$ & $7.1 \pm 0.2 \mathrm{~B}$ & $6.7 \pm 0.3 \mathrm{~B}$ \\
\hline
\end{tabular}

well with the different levels of geosmin in the fish (although geosmin did not appear to be a dominant offflavour). An advantage of the local panel is that its members can identify flavour preferences by Bangladeshi consumers, implying that their grading is valuable to fish farmers in the region. observed for pangas but not for tilapia (the geosmin content was unchanged after depuration in tilapia), might point to geosmin as a dominant component in the perceived off-flavour. However, in sensory studies of channel catfish and rainbow trout, the human threshold for geosmin detection was determined as $\sim 250 \mathrm{ng} \mathrm{kg}^{-1}$ fish (Grimm et al. 2004, Robertson et al. 2005, Robin et al. 2006), although a slightly lower threshold of $\sim 100 \mathrm{ng} \mathrm{kg}^{-1}$ fish was found for rainbow trout by Petersen et al. (2011). In the Patuakhali ponds, the maximum geosmin content was 68 and $91 \mathrm{ng} \mathrm{kg}^{-1}$ for tilapia and pangas, respectively. Assuming that the detection threshold of geosmin is identical for catfish, trout, pangas, and tilapia, our results indicate that compounds other than geosmin caused the off-flavour in the Patuakhali fish. MIB is frequently reported as a major off-flavour compound in fish (Tucker 2000), but our analyses suggest that this compound occurred at similar or lower concentrations in fish in this study. Unfortunately, MIB coeluted with an unknown compound and could not be properly quantified.

The positive effect of off-flavour reduction after only $12 \mathrm{~h}$ of depuration is surprising, e.g. when compared to depuration of rainbow trout Onchorhynchus mykiss for several days to obtain a content below the human threshold level (Robertson et al. 2005). Although the initial off-flavour (geosmin) content was higher in the rainbow trouts, the warmer water in Bangladesh $\left(\sim 30^{\circ} \mathrm{C}\right.$, or $15^{\circ} \mathrm{C}$ above the temperature used during the depuration of the rainbow trout) probably increased the off-flavour removal due to a high metabolic rate. Supporting a temperature effect, Jones et al. (2013) also observed an efficient reduction of geosmin in barramundi in water at $26^{\circ} \mathrm{C}$ after $24 \mathrm{~h}$.

The sensory panel in this study did not receive training in identification of specific off-flavours or in description of sensory properties, and thus, comparison of off-flavour grading by this panel and trained panels in other studies is problematic. Yet, despite the lack of training, grading by the panel agreed

\section{Potential producers of off-flavours}

Since streptomycete bacteria and cyanobacteria are recognized as notorious off-flavour producers in freshwater, including aquaculture systems (Zaitlin \& Watson 2006), abundances of these 2 groups of microorganisms were determined in the ponds. The density of Streptomyces bacteria in the pond water varied from $0.21 \times 10^{9} \mathrm{l}^{-1}$ to $4.2 \times 10^{9} \mathrm{l}^{-1}$ (Fig. 1). Large seasonal and pond-to-pond variations, even between duplicate ponds, occurred. A general trend, however, was presence of higher densities in March than in May and July ( $p<0.05 ;$-test). Except for the high density in AquaPhoto Pond \#1 at March 25, water treatment by sand filtration or probiotics resulted in lower densities of streptomycetes, relative to the controls, in March, but this trend was not found in May and July. The density of all bacteria in the pond

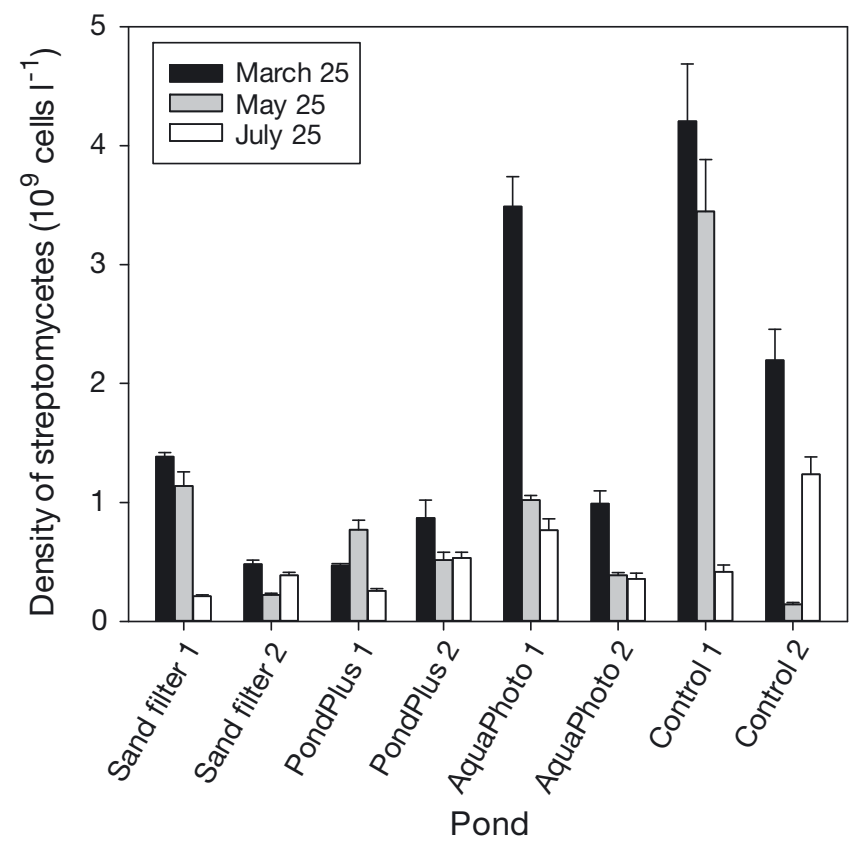

Fig. 1. Abundance of Streptomyces in the different ponds during the growth period. Mean values of triplicate samples (on filter divided into 3 portions) \pm 1 SD are shown 
water was not determined, but the abundance of bacteria in 4 similar fish ponds in the area was determined in December 2011 as $23 \times 10^{9}$ to $32 \times 10^{9}$ cells $1^{-1}$ (data not shown). Assuming that these densities are also representative of the 8 studied ponds, streptomycete bacteria made up 0.45 to $13.3 \%$ (mean of $3.4 \%$ ) of all bacteria.

Occurrence of Streptomyces in aquatic environments is relatively non-documented, but they are assumed potential contributors of off-flavours (Klausen et al. 2005). Using cultivation methods, densities of $10^{2}$ to $10^{5}$ streptomycetes $1^{-1}$ were found in various freshwater environments (Lanciotti et al. 2003, Lee et al. 2011), while fluorescence in situ hybridization, targeting rRNA, indicated up to $2 \times 10^{9}$ cells $\mathrm{l}^{-1}$ in a water reservoir (Nielsen et al. 2006). In contrast, using the present PCR approach, Lylloff et al. (2012) only found up to $46 \times 10^{3}$ streptomycetes $1^{-1}$ in various Australian freshwaters. Relative to these studies, the present abundance of Streptomyces in the Patuakhali ponds appears relatively high. The low concentrations of geosmin in the pond water suggest that streptomycetes, although abundant, were not significant producers of geosmin in the water during the studied period.

Cyanobacteria made up a relatively small portion of the plankton biomass during the study, ranging from $0.7 \%$ (May 25) to $1.9 \%$ (July 25) of the phytoplankton biomass (based on chlorophyll a) (Fig. 2). The highest abundance $(9.3 \%$ of the biomass) occurred in AquaPhoto Pond \#2 on 25 March. Treatment of the water (sand filtration or probiotics) reduced the abundance of cyanobacteria by $69 \%$ relative to the controls ( $p<0.02$; Mann-Whitney rank sum test of all samples). The phytoplankton community was dominated by chlorophytes (green algae), followed by diatoms and cryptophytes, making up $53-76 \%, 13-23 \%$, and $7.5-22 \%$, respectively, of the mean biomass from March to July.

The pigment analyses indicate that cyanobacteria had a low abundance among phytoplankton in the ponds. Microscopy analysis of phytoplankton in some fish ponds in the region, e.g. in the main PSTU campus fish pond, showed that the phytoplankton in May and June 2013 was dominated by Oscillatoria, Microcystis, Anabaena, and other cyanobacterial species (data not shown). This contrasts our observations of phytoplankton populations determined by pigment analysis. Here, cyanobacteria were identified by the pigments myxoxanthophyll, echinenone, and canthaxanthin. Myxoxanthophyll and echinenone have been found in selected species of Oscillatoria and Microcystis (Schlüter et al. 2006), while Ana-


Fig. 2. Concentrations of chlorophyll $a$ and composition of major groups of phytoplankton in the ponds determined by pigment and CHEMTAX analyses. For each sampling, result from 1 filter is shown

baena spp. may contain all 3 pigments (Schlüter et al. 2004). These 3 cyano-pigments were only present in some of the samples and in relatively small concentrations, as reflected in Fig. 2. Zeaxanthin is another cyanobacterial pigment that was detected in all samples in relatively low concentrations. However, zeaxanthin is also present in chlorophytes and has limited value as diagnostic pigment in the present study, where chlorophytes dominated.

Pheophytin a and pheophorbide a (degradation products of chlorophyll $a$; not included in the CHEMTAX calculations) were present in considerable amounts in some samples and constituted up to $27 \%$ of chlorophyll a (average of $14 \%$ of chlorophyll a in all samples). These degradation products indicate a considerable breakdown of phytoplankton in the ponds. 
Cyanobacteria are assumed dominant producers of off-flavours in open, outdoor aquaculture systems due to presence of sunlight and inorganic nutrients (Tucker 2000, Schrader \& Dennis 2005). In the Patuakhali ponds, the low content of both cyanobacteria and geosmin suggests that cyanobacteria were not major producers of off-flavours in the water. However, more information on species of cyanobacteria and their potential production of off-flavours in the ponds is needed to draw conclusions, e.g. on the risk of off-flavour episodes due to cyanobacteria.

\section{CONCLUSION}

The off-flavour geosmin in pangas and tilapia from the Bangladeshi ponds was below the human detection threshold based on other studies of off-flavours in fish, and geosmin probably did not contribute to tainting of the fish. The chemical analyses demonstrated that treatment of the pond water (via sand filtration or probiotic microbes) and depuration for at least $12 \mathrm{~h}$ reduced the geosmin content in pangas but not in tilapia. Sensory studies confirmed a positive effect of both water treatment and depuration on the off-flavour content of the fish, especially for pangas. This improvement of the sensory quality, despite the fact that the geosmin content appeared to be consistently below the human threshold, suggests that offflavour compounds other than geosmin were present in water and fish. Studies are underway to demonstrate whether phytoplankton, vegetation, or anthropogenic sources may contribute to the off-flavour content in water and fish in Bangladeshi ponds.

Acknowledgements. We thank the Regional Fisheries \& Livestock Development Component - Barisal TSU, Danish International Development Assistance (Danida)/Government of Bangladesh, Barisal, Bangladesh, for providing a grant for this study. Technician Ulla Rasmussen, University of Copenhagen, is acknowledged for skillful PCR analyses of streptomycetes.

\section{LITERATURE CITED}

Ahmed N, Young J, Dey M, Muir J (2012) From production to consumption: a case study of tilapia marketing systems in Bangladesh. Aquacult Int 20:51-70

> Auffret M, Yergeau É, Pilote A, Proulx É and others (2013) Impact of water quality on the bacterial populations and off-flavours in recirculating aquaculture systems. FEMS Microbiol Ecol 84:235-247

Burr GS, Wolters WR, Schrader KK, Summerfelt ST (2012) Impact of depuration of earthy-musty off-flavors on fillet quality of Atlantic salmon, Salmo salar, cultured in a recirculating aquaculture system. Aquacult Eng 50:28-36
Engle CR, Pounds GL, van der Ploeg M (1995) The cost of off-flavor. J World Aquacult Soc 26:297-306

- Grimm CC, Lloyd SW, Zimba PV (2004) Instrumental versus sensory detection of off-flavors in farm-raised channel catfish. Aquaculture 236:309-319

Gutierrez R, Sompong U, Prarom W, Iwami N, Itayma T, Nomura N, Sugiura N (2013) Off-flavour in Nile tilapia (Oreochromis niloticus) cultured in an integrated pondcage culture system. Maejo Int J Sci Tech 7(Spec Issue): $1-13$

Higgins H, Wright S, Schlüter L (2011) Quantitative interpretation of chemotaxonomic pigment data. In: Roy $\mathrm{S}$ (ed) Characterization, chemotaxonomy and applications in oceanography. UNESCO, Paris, p 257-313

> Houle S, Schrader KK, Le Francois NR, Comeau Y and others (2011) Geosmin causes off-flavour in arctic charr in recirculating aquaculture systems. Aquacult Res 42: 360-365

Howgate P (2004) Tainting of farmed fish by geosmin and 2-methyl-iso-borneol: a review of sensory aspects and of uptake/depuration. Aquaculture 234:155-181

Hurlburt BK, Brashear SS, Lloyd SW, Grimm CC, Thomson JL, Zimba PV (2009) Impact of weather on off-flavour episodes at a Louisiana commercial catfish farm. Aquacult Res 40:566-574

Jones B, Fuller S, Carton AG (2013) Earthy-muddy tainting of cultured barramundi linked to geosmin in tropical northern Australia. Aquacult Environ Interact 3:117-124

Khan S, Hossain MS, Haque MM (2009) Effects of feeding schedule on growth, production and economics of pangasiid catfish (Pangas hypophthalmus) and silver carp (Hypophthalmichthys molitrix) polyculture. J Bangladesh Agricult Univ 7:175-181

Klausen C, Nicolaisen MH, Strobel BW, Warnecke F, Nielsen JL, Jørgensen NOG (2005) Abundance of actinobacteria and production of geosmin and 2-methylisoborneol in Danish streams and fish ponds. FEMS Microbiol Ecol 52:265-278

Lanciotti E, Santini C, Lupi E, Burrini D (2003) Actinomycetes, cyanobacteria and algae causing tastes and odours in water of the River Arno used for the water supply of Florence. J Water Supply Res Technol 52:489-500

> Lee GC, Kim YS, Kim MJ, Oh SA and others (2011) Presence, molecular characteristics and geosmin producing ability of Actinomycetes isolated from South Korean terrestrial and aquatic environments. Water Sci Technol 63: 2745-2751

> Lylloff JE, Mogensen MH, Burford MA, Schlüter L, Jørgensen NOG (2012) Detection of aquatic streptomycetes by quantitative PCR for prediction of taste-and-odour episodes in water reservoirs. J Water Supply Res Technol 61:272-282

> Mackey MD, Mackey DJ, Higgins HW, Wright SW (1996) CHEMTAX - a program for estimating class abundances from chemical markers: application to HPLC measurements of phytoplankton. Mar Ecol Prog Ser 144: 265-283

Mohsin M, Bakar J, Selamat J (1999) The effects on colour, texture and sensory attributes achieved by washing black tilapia flesh with a banana leaf ash solution. Int J Food Sci Technol 34:359-363

Nielsen JL, Klausen C, Nielsen PH, Burford MA, Jørgensen NOG (2006) Detection of activity among uncultured Actinobacteria in a drinking water reservoir. FEMS Microbiol Ecol 55:432-438 
Percival S, Drabsch P, Glencross B (2008) Determining factors affecting muddy-flavour taint in farmed barramundi, Lates calcarifer. Aquaculture 284:136-143

Petersen MA, Hyldig G, Strobel BW, Henriksen NH, Jørgensen NOG (2011) Chemical and sensory quantification of geosmin and 2-methylisoborneol in rainbow trout (Oncorhynchus mykiss) from recirculated aquacultures in relation to concentrations in basin water. J Agricult Food Chem 59:12561-12568

Rintala H, Nevalainen A (2006) Quantitative measurement of streptomycetes using real-time PCR. J Environ Monit 8:745-749

Robertson RF, Lawton LA (2003) Off-flavor problems and a potential solution within the UK trout industry. ACS Symp Ser 848:55-68

Robertson RF, Jauncey $\mathrm{K}$, Beveridge MCM, Lawton LA (2005) Depuration rates and the sensory threshold concentration of geosmin responsible for earthy-musty taint in rainbow trout, Onchorhynchus mykiss. Aquaculture 245:89-99

Robin J, Cravedi JP, Hillenweck A, Deshayes C, Vallod D (2006) Off flavor characterization and origin in French trout farming. Aquaculture 260:128-138

Schlüter L, Garde K, Kaas H (2004) Detection of the toxic cyanobacteria Nodularia spumigena by means of a

Editorial responsibility: Megan La Peyre,

Baton Rouge, Louisiana, USA 4-keto-myxoxanthophyll-like pigment in the Baltic Sea. Mar Ecol Prog Ser 275:69-78

Schlüter L, Lauridsen TL, Jørgensen T, Krogh G (2006) Identification and quantification of phytoplankton groups in lakes using new pigment ratios - a comparison between pigment analysis by HPLC and microscopy. Freshw Biol 51:1474-1485

Schrader KK, Dennis ME (2005) Cyanobacteria and earthy/musty compounds found in commercial catfish (Ictalurus punctatus) ponds in the Mississippi Delta and Mississippi-Alabama Blackland Prairie. Water Res 39: $2807-2814$

Smith JL, Boyer GL, Zimba PV (2008) A review of cyanobacterial odorous and bioactive metabolites: impacts and management alternatives in aquaculture. Aquaculture 280:5-20

$>$ Tucker CS (2000) Off-flavor problems in aquaculture. Rev Fish Sci 8:45-88

Van Heukelem L, Thomas C (2001) Computer assisted highperformance liquid chromatography method development with applications to the isolation and analysis of phytoplankton pigments. J Chromatogr A 910:31-49

> Zaitlin B, Watson SB (2006) Actinomycetes in relation to taste and odour in drinking water: myths, tenets and truths. Water Res 40:1741-1753

Submitted: October 14, 2013; Accepted: March 20, 2014 Proofs received from author(s): April 16, 2014 